\title{
«La Inquisición no conoce de nosotros los indios». Fiesta y escándalo en el Corpus Christi*
}

\author{
por \\ Mariana C. Zinni' ${ }^{1}$ \\ Queens College / City University of New York
}

En 1661, durante la fiesta del Corpus Christi en la doctrina de Ambar, en ausencia del cura doctrinero, se produjeron una serie de episodios catalogados como idolátricos, llevados a cabo por los naturales del pueblo, que incluyeron la celebración de una falsa misa, la unión en matrimonio de una pareja de hombres disfrazados y el bautizo del fruto de tal unión. En este artículo propongo una lectura de estos incidentes con el propósito de estudiar el accionar de un grupo de individuos que ostentaban distintos grados sociales y acceso al poder -el sacristán indio, el curaca, el falso celebrante-, quienes se valieron de esta ocasión para socavar la autoridad del cura doctrinero ante el tribunal eclesiástico, creyendo quedar fuera del alcance del mismo por su condición de indios. Sin embargo, nada salió como lo planearon $y$ los eventos culminaron de manera muy diferente.

Palabras clave: doctrina de indios; Inquisición; Corpus Christi; capitulos; Andes coloniales.

Cómo Citar Este Artículo / Citation: Zinni, Mariana C., “«La Inquisición no conoce de nosotros los indios». Fiesta y escándalo en el Corpus Christi”, Revista de Indias, LXXXI/282 (Madrid, 2021): 315-343. https://doi.org/10.3989/revindias.2021.009.

* Parte de esta investigación fue financiada con una beca otorgada por el Professional Staff Congress - City University of New York en el verano de 2015 [Award 66150-00-44].

Agradezco al personal del Archivo Arzobispal de Lima, en especial a su directora, la Dra. Laura Gutiérrez y a Melecio Tineo Morón por haberme facilitado el acceso a los documentos y expedientes solicitados. Asimismo quiero hacer extensivo mi agradecimiento al Dr. Nicolás Vivalda (Vassar College) por su invaluable asistencia en el proceso de digitalización de los materiales.

${ }^{1}$ mariana.zinni@qc.cuny.edu, ORCID iD: https://orcid.org/0000-0001-8105-4710 de uso y distribución Creative Commons Reconocimiento 4.0 Internacional (CC BY 4.0). 
Si la única manera de reivindicar un lugar es imponiéndose como cristiano, la única arma para ganar terreno político fuera de los cargos del cabildo y la doctrina es reclamarse indio.

Juan Carlos Estenssoro Fuchs (2003).

Las fiestas, en especial las fiestas solemnes de carácter religioso, sirvieron durante los años del virreinato español en América no solo para reafirmar la dominación eclesiástica y civil en todo su boato, sino también como escenario de transgresiones más o menos permitidas por las autoridades, $\mathrm{y}$, en buena medida, para escenificar determinadas negociaciones en torno a la identidad cristiana de los pueblos indígenas. En este artículo propongo una lectura de los episodios ocurridos durante la fiesta del Corpus Christi que se celebró en el pueblo de Nuestra Señora de la Asunción, de la doctrina de Ambar, provincia de Cajatambo, en el corazón de los Andes, con el propósito de estudiar el accionar de un grupo de individuos que ostentaban distinto estatus social y acceso al poder - el sacristán indio, el curaca, el falso celebrante-, quienes se valieron de esta ocasión para socavar la autoridad del cura doctrinero ante el tribunal eclesiástico. Una de las posibilidades de lectura de este largo expediente en la que centraré mis argumentos radica en la idea de que los naturales, al provocar un escándalo de corte idolátrico y, a la vez, reconociendo y utilizando los recursos del sistema legal colonial, quisieran remover a un cura abusivo sin la necesidad de recurrir al engorroso trámite de capitularle. Sin embargo, estos argumentos idolátricos probarán ser un arma de doble filo que permite vislumbrar un mundo de intrigas, acusaciones y sospechas que leemos en los documentos, y que ocurren también en doctrinas pequeñas como la de Ambar.

Veamos qué sucedió. El domingo 8 de junio de 1661, en la parroquia de la Advocación de la Asunción de Nuestra Señora de Ambar, provincia de Cajatambo, una doctrina de indios enclavada en los Andes centrales, los feligreses se dispusieron a celebrar con toda la pompa y solemnidad prescripta las festividades, misa y procesión del Corpus Christi. Sin embargo, esta edición de la fiesta dará pie a un escándalo público que terminará cinco años más tarde y con la intervención del Tribunal Eclesiástico de Lima². Como era costumbre, la feligresía engalanada se reunió en la plaza central de la doctri-

${ }^{2}$ Causa contra don Rodríguez Pilco, cacique y gobernador del pueblo de Ambar, por haber permitido a un yndio el hacer un simulacro de misa y de bautismo en la fiesta del Corpus, Archivo Arzobispal de Lima, Lima (AAL), Hechicerías e Idolatrías, leg. IIA, exp. 12, Ambar 1661/1662, 370 ff. 
na, adornada con flores, ramadas, plumas y altares móviles ${ }^{3}$, a cantar himnos en honor a la Sagrada Forma expuesta en su custodia en la explanada de la capilla, y a escuchar la Santa Misa oficiada en su honor por el cura doctrinero, el licenciado Juan de Salazar Montesinos ${ }^{4}$. Una vez finalizada la misa, los fieles, precedidos por sus autoridades étnicas y los miembros del cabildo local, llevaron a cabo un banquete en la plaza, regado con gran cantidad de chicha y acompañado de música y danzas tradicionales andinas, entre ellas, varios bailes de máscaras y takis. El cura, invitado por las autoridades locales, se excusó y no participó de la comida alegando negocios personales en una granja cercana de su propiedad, sin saber que tal acción conduciría a un escándalo de proporciones, con prácticas idolátricas incluidas, y que lo llevaría a ser acusado por el tribunal eclesiástico de negligencia pastoral.

En medio de la celebración, y visiblemente embriagados, los naturales realizaron una serie de imitaciones y transgresiones del ritual católico, desde la usurpación de la dignidad sacerdotal y oficio de una falsa misa por parte del indio Francisco Martín, quien disfrazado con una sobrepelliz y barbas falsas, elevó una hostia de papel y chicha en un k'ero al momento de la consagración, hasta la celebración del matrimonio de una pareja de hombres disfrazados, uno de los cuales dio a luz un envoltorio de trapos en forma de muñeca, bautizado inmediatamente por el falso cura. Enardecido por tal blasfemo espectáculo, Agustín Capcha, el sacristán indio de la doctrina, intentó poner un freno al desarrollo de los eventos, siendo perseguido y golpeado duramente por el curaca don Juan Rodríguez Pilco. Salvó su vida al refugiarse en la sacristía ${ }^{5}$. Interpelado el curaca por un grupo de españoles y mestizos que salieran en defensa del sacristán «que si lo supiera el Sancto Tribunal de la Inquisicion fuera castigado rigurosamente», respondió airosamente el gobernador «que la Inquisicion no conoce de los yndios» ${ }^{6}$, pero parece olvidar que sí están bajo el fuero de la justicia eclesiástica ordinaria ${ }^{7}$.

${ }^{3}$ Véase Zevallos Quiñones, 1978, quien hace un minucioso relevamiento documental de la distribución de arcos, luminarias, altares y función de cada participante en la fiesta del Corpus Christi de Cajamarca en 1684 que sirve para ponernos en situación respecto de la celebrada en Ambar en 1661, a pesar de que aquí se trate de una doctrina pequeña.

${ }^{4}$ Sobre la fiesta del Corpus Christi de 1661 celebrada en Ambar, véase Zinni, 2017.

5 Para una descripción detallada de estos eventos, remito nuevamente a Zinni, 2017.

${ }^{6}$ Causa contra don Rodríguez Pilco, cacique y gobernador del pueblo de Ambar, por haber permitido a un yndio el hacer un simulacro de misa y de bautismo en la fiesta del Corpus, AAL, Hechicerías e Idolatrías, leg. IIA, exp. 12, Ambar 1661/1662, f. 2.r, énfasis agregado.

${ }^{7}$ La Inquisición se instituye en Castilla en 1478, a instancias de los Reyes Católicos, y se extiende a América por Real Cédula firmada por Felipe II en 1569. El 29 de enero de 1570 se celebra en Lima una misa solemne con motivo de la llegada de los primeros inquisidores, 
En ausencia del cura, los principales del pueblo pretendieron reemplazar a Agustín Capcha relevándolo de su cargo de sacristán. Lo acusaron de haberle faltado al respeto a su curaca, de haber llevado una conducta impropia y de emborracharse, y nombraron en su lugar a Juan Álvarez, indio ladino. Juan de Salazar Montesinos, vuelto a su doctrina, se encontró con el escándalo, un nuevo sacristán que desconoce como tal, y el deber de castigar a Capcha, su ahijado y compadre refugiado en la sacristía, por haber provocado y enseñado, según la versión del curaca, la idolatría. El escándalo se desvela un par de meses más tarde ante el Tribunal Eclesiástico cuando Salazar Montesinos se ve obligado a denunciarlo en el marco de la inminente visita del licenciado Juan Sarmiento de Vivero. El 30 de junio de 1662, casi un año después de los eventos, se publicaron los cargos formales: a Juan de Salazar Montesinos, como cura propietario de la doctrina, se lo acusó de negligencia pastoral por haber abandonado a su feligresía y permitido los excesos; por

auspiciados por el virrey Toledo. El Santo Oficio se establece en las colonias no con el propósito de perseguir herejes, sino, en primera instancia, por la preocupación de la moral clerical y con el fin de fortalecer a todos en los sacramentos y vigilar el correcto adoctrinamiento de la fe por parte de predicadores y religiosos, además de atender a los delitos propios del clero. Felipe II extiende una Real Cédula firmada el 30 de diciembre de 1571 que prohíbe a los inquisidores conocer de las causas de fe contra los indios, fundamentada en la incapacidad relativa de los indígenas y en su condición de neófitos en la fe (Millar Carvacho, 1998: 283). Las Instrucciones para Inquisidores de Indias dictadas en Madrid el 15 de febrero de 1560 establecen que «Item se os advierte que, en virtud de vuestros poderes, no habréis de proceder contra los indios de vuestro districto, porque por ahora y hasta que otra cosa se os ordene, es nuestra voluntad que sólo useis dellos contra los cristianos viejos y las otras personas contra quien en estos reynos de España se suele proceder» (Instrucción para Inquisidores de Indias, Archivo Histórico Nacional (Madrid), Inquisición, libro 352, ff. 4v al 10v). Tal condición excluía a los naturales del fuero inquisitorial, pero no de la justicia eclesiástica.

Los indígenas quedan bajo el fuero de la corte episcopal del arzobispado, conocida como Provisorato de Indios, aunque la Inquisición hizo varios intentos de extender su jurisdicción sobre ellos. Sobre los alcances del fuero inquisitorial, véase Greenleaf, 1965: 149, quien analiza la confusión que reinaba entre el clero respecto de la jurisdicción del Santo Oficio sobre la población nativa en el ámbito de la Nueva España. Esta confusión comienza a ser delimitada a partir de la pregunta por la limpieza de sangre, es decir, quién era y cómo se definía la categoría de «indio puro». En el virreinato del Perú las condiciones fueron un tanto diferentes. Gareis $(1999 ; 2004)$ analiza estas diferencias. Sobre los fueros de indios, véase Gareis, 1989, donde particularmente se discute la intención del virrey Toledo de terminar con las distinciones entre neófitos y cristianos viejos.

Para un estudio más completo sobre la jurisdicción del Santo Oficio en las Indias, véase asimismo Medina, 1887. Mills, 1997. Domínguez Reboiras, 2010. Castañeda Delgado y Hernández Aparicio, 1989, en especial el capítulo V. Ramos, 1991; 1989. Millar Carvacho, 1998. Para una bibliografía exhaustiva sobre la Inquisición en el Perú entre 1950 y 1996, véase Hampe-Martínez, 1996. 
castigar al sacristán — quien alegaba haber intentado detener a Francisco Martín - con el objeto de complacer a Rodríguez Pilco e impedir que éste lo capitulase $^{8}$; y por retrasar unos meses la denuncia del escándalo con el objetivo de ganar tiempo y negociar con el curaca. A Francisco Martín, Rodríguez Pilco y su hermano, el principal don Juan de Alvarado, se los acusó de haber hecho irrisión y burla de los santos sacramentos del bautismo y la misa. Agustín Capcha resultó sobreseído de todos los cargos que intentó presentar en su contra el curaca, fue promovido al cargo de fiscal mayor del corregimiento de Cajatambo, y ofició como tal en parte del proceso en cuestión'.

A pesar de que los eventos desarrollados tienen un marcado corte idolátrico, en este trabajo no se pretende estudiar las representaciones o reactualizaciones de un culto «andino» —razón por la cual no se hará hincapié en las campañas de extirpación de idolatrías en los Andes-, aunque por momentos notemos cierta «andinización» del culto católico en el accionar de los indígenas, como por ejemplo en la utilización de un k'ero — vaso ceremonial incay el hecho de utilizar chicha en lugar de vino para la consagración, lo que denotarían una suerte de representación en tono de burla de la ceremonia de la misa. Lo que interesa en esta nueva aproximación al expediente de Ambar es «una actuación del poder por parte de los naturales» ${ }^{10}$ con el objetivo de provocar un escándalo, puesto que lo que sucede en esta doctrina es la celebración pública y notoria de una misa falsa, sobre la cual tenemos antecedentes inmediatos - como veremos en la fiesta de la Candelaria, incluso con los mismos actores-, y antecedentes posteriores, como los notificados por el fiscal eclesiástico, Agustín Capcha, ocurridos en Gorgor durante el Corpus del año siguiente de $1662^{11}$.

Al parecer, y esta es una de las líneas argumentales que intento explorar, uno de los motivos por los que se desarrolló este escándalo pudo haber sido el deseo de remover de la doctrina a un cura considerado abusivo, dueño de obrajes y granjerías en las cuales obligaría a sus fieles a trabajar por poca o

${ }^{8}$ La bibliografía sobre capítulos es muy abundante, sobre todo la referida a los capítulos a los que el padre Ávila es sometido y que darían pie al descubrimiento de las idolatrías de Huarochirí y el posterior surgimiento de las campañas de extirpación. Algunos textos que abordan el tema de manera más general son los estudios de Duviols, 1977. Acosta, 1977. Hunefeldt, 1983. Spalding, 1984. García Cabrera, 1994. Rowe, 1957. Rivarola, 2010, entre otros.

${ }^{9}$ Causa contra don Rodríguez Pilco, cacique y gobernador del pueblo de Ambar, por haber permitido a un yndio el hacer un simulacro de misa y de bautismo en la fiesta del Corpus, AAL, Hechicerías e Idolatrías, leg. IIA, exp. 12, Ambar 1661/1662, f. 98r.

10 Zinni, 2017: 192.

11 García Cabrera, 1994: 397, 415. 
nula paga ${ }^{12}$. De esta manera, se evitaría pasar por las situaciones de pleitos fallidos y capítulos inciertos, que habrían de probarse largos e inútiles, y, la mayoría de las veces, contraproducentes para los indios capitulantes, quienes solían ser acusados por el doctrinero de idolatría a modo de represalia. Por su lado, los doctrineros temían la utilización de falsos capítulos que los indios levantaban en contra suya, y que podían terminar con su carrera: «Les dexan hazer [a los indios] lo que quieren porque muy facilmente se conjuran quatro o cinco para levantar falsos testimonios y poner capítulos a los curas $\rangle^{13}$. La mayoría de las veces estos capítulos no eran falsos, sino que se constituían en la única arma legal al alcance de los indios para denunciar abusos y exacciones desorbitantes de parte de sus propios doctrineros o de los mismos visitadores $^{14}$.

12 Sobre los aspectos económicos de las doctrinas y las relaciones de los curas doctrineros con obrajes, granjerías y prácticas coloniales de explotación, véase Lavallé, 1982 y García Cabrera, 1994. Sobre conflictos, en su mayoría económicos o jurisdiccionales, entre curacas y doctrineros, véase a manera de introducción al tema Spalding, 1984; 1974; 1973. Ramírez, 1996. Cahill, 1984. Acosta Rodríguez, 1979; 1982a; 1982b; 1987. Flores Galindo, 1987. Puente Luna, 2007. Millones, 1978; 1984. Lavallé, 1992. Hampe Martínez, 1996. Monsalve, 1998. Rivarola, 2010. Recordemos que los indios podían iniciar procedimientos judiciales contra párrocos y sacerdotes asistentes por medio de una demanda presentada a través de la oficina del protector de los naturales y que comenzaba con una carta dirigida a la Audiencia correspondiente. Los pleitos, como sabemos, eran largos y costosos, aunque hubo casos de indios «inusitadamente persistentes... Todo demuestra su compromiso para utilizar cualquier herramienta judicial limitada a su alcance para aliviar su condición. Dichos esfuerzos podían tomar meses, e inclusive años, y tenían un resultado menos seguro» (Robins, 2009: 17).

13 Citado en Duviols, 1997: 403.

${ }^{14}$ El visitador actuante en la primera parte del proceso que nos ocupa, el licenciado Juan Sarmiento de Vivero, fue capitulado numerosas veces por exacciones excesivas, una de ellas por los mismos indios de Ambar, protagonistas de este caso. En el folio 48v del expediente analizado hay una lista de bienes que se le entregan al visitador que incluye gallinas, pollos, velas, camarones, «anchovitas», frutas, papas, coles, etc. Revisando otras causas bajo la signatura de Visitas Pastorales del Archivo Arzobispal de Lima, encontramos también un dato de 1665 en el cual se explicita que en el curato de San Juan de Lampián el cacique se queja de los excesivos gastos y costas de la visita de Sarmiento de Vivero, y detalla asimismo una serie de bienes que le fueron entregados (gallinas, pollos, carneros, manteca, papa, maíz, huevos). En Pacaraos denuncian que Juan Sarmiento de Vivero cobraba 8 pesos por procuración a cada indígena, 4 reales por cada santo y 200 pesos por cofradías, y que lo había hecho en ocho iglesias, y solicitaban la devolución de ese cobro (Querella seguida contra el licenciado Juan Sarmiento de Vivero por los caciques de San Juan de Lampián, AAL, Visitas Pastorales, leg. 5, exp. 6, Lima 1665, 5 ff.). En el mismo año de 1665 se le acusa de crueldad y corrupción en la parroquia de Canta y en 1662 se lo denuncia por explotación de indígenas y confiscación de bienes e incluso de venta de tierras pertenecientes a las huacas del asiento de Puris, quedándose con ese dinero (Causa criminal de idolatrías contra algunos indígenas de Canta, AAL, Hechicerías e Idolatrías, leg. 1, exp. 1669). 
Los sucesos de Ambar habrían tenido un propósito político inmediato para evitar la lentitud e ineficacia de los capítulos, es decir, la necesidad de recurrir a alguna forma de disrupción social en defensa de determinadas expectativas de justicia. En otras palabras, los naturales estarían ante la oportunidad de cuestionar ciertos mecanismos de explotación económica en el mundo andino mediante la coordinación de estrategias - no siempre del todo legales- de resistencia. Este episodio en particular nos llevará a reflexionar a partir de una fiesta religiosa como la del Corpus Christi en los Andes sobre cuestiones que atañen a las relaciones sociales, políticas, jurídicas y económicas entre los feligreses, las autoridades étnicas y el clero.

La CANDElaria: «POR esta CAUSA SE ATREVIERON los yNDIOS A BOlVER A HACER»

Los sucesos de Ambar tuvieron un antecedente local del cual participaron los mismos personajes y que intentó ser utilizado como atenuante de lo ocurrido durante el Corpus. El 2 de febrero de 1661 se celebró en esta doctrina la fiesta de la virgen de la Candelaria con sus pompas habituales. Si bien no hay una descripción detallada de la misma en los testimonios que conforman el expediente estudiado, tenemos noticias de que ocurrió un incidente que funcionará en un doble sentido: como referencia y paliativo. Respondiendo a las acusaciones del cura a través del Procurador General de los Naturales, don Joseph Mexia de Estela, don Juan Rodríguez Pilco se defiende trayendo a colación lo ocurrido durante este festejo arguyendo que él mismo

... no solo no coopero ni fomento a los dhos yndios en el exceso y delito que cometieron sino que lo reprehendio y acudio a su obligacion siendo assi que ellos tuvieron exemplo para poderlo hacer pues aviendo sucedido el mismo casso el dia de nuestra señora de la Candelaria en presencia y con asistencia del dho licenciado Juan de salazar montesinos no solo no lo rreprehendio sino que lo permitio y tolero con que los yndios se persuadieron a que era licito ${ }^{15}$.

El hecho, de gravedad, se incluye en las probanzas que prepara Rodríguez Pilco para su defensa que se utilizan en los interrogatorios a los testigos de su parte y de donde extraeremos, aunque parcial, información crucial para nuestro caso. Dice la pregunta correspondiente a este hecho:

15 Causa contra don Rodríguez Pilco, cacique y gobernador del pueblo de Ambar, por haber permitido a un yndio el hacer un simulacro de misa y de bautismo en la fiesta del Corpus, AAL, Hechicerías e Idolatrías, leg. IIA, exp. 12, Ambar 1661/1662, f. 163v. 
[8] Yten si sauen que auiendo sucedido lo mismo que sucedio un Domingo inmediato al dia de corpus christi el dia de Maria de la Candelaria el mismo año de seiscientos y sesenta y uno estando presente el Licenciado Juan de salazar montesinos hicieron las mesmas ceremonias y no solo no lo prohiuio sino lo consintio y permitio olgandose y rreiendose poblicamente con que los yndios persuadidos a que era licito repitieron lo mesimo luego con las mismas bestiduras el dho dia de corpus christi digan--- ${ }^{16}$.

El testimonio del indio Juan Bautista informó que esta vez el falso oficiante de la misa fue el acusado sacristán, Agustín Capcha (f. 164r). Y agregó en su interrogatorio:

A la octaua pregunta $=$ Dixo que por auerlo visto que susedio antes deste dia del corpus el dia de Sra de la candelaria del mismo año en el dho pueblo de ambar con las mismas bestiduras altar calis y lo demas que bio en el para la solednidad de la fiesta dha de la candelaria y en ellas asistio a dhos juegos el dho Lido Juan de Salaçar montesinos y que no solo no rreprehendio dhos juegos antes los aprobo riendose y diciendo a los yndios mira buestro cura agustin capcha es buestro cura oyrle su misa con que los yndios por sucedidos de aquel aliciente repitieron el mesmo juego el dho dia del corpus y esto responde---- ${ }^{17}$.

Según varios testimonios ${ }^{18}$, el doctrinero no solo fue testigo de estas ceremonias, sino que las permitió y hasta alentó, riendo y avalando esta usurpación del oficio del sacerdocio de parte de su propio ahijado indio. Lo sorpresivo aquí es que el falso cura fue Agustín Capcha, quien, según el testimonio del indio ladino Martín Capcha, había enseñado a Francisco Martín las ceremonias de la misa ${ }^{19}$. Los testigos, instruidos seguramente por Rodríguez Pilco, mencionaron este hecho como justificación y atenuante del escándalo del Corpus: al no haber sido condenado por Salazar Montesinos en su momento, no debió ser considerado pecado, ejercicio de la idolatría, o mal accionar de

16 Ibidem, f. 204v.

${ }^{17}$ Ibidem, f. $217 \mathrm{v}$, énfasis agregado.

${ }_{18}$ Entre los indios que testifican a favor de su cacique encontramos a Martín de Todos los Santos, Juan Caxa Condor, Juan Culca o Xulca, Francisco Pascual, Miguel Hernandez, Anton Delgado, Juan Guaman, Pedro Pariguaman, y Diego Pheliphe, entre otros. Muchos de estos nombres aparecen en calidad de acusados en documentos posteriores, firmados por Agustín Capcha, ya en su función de fiscal mayor y, en general, aparecen también en pleitos por amancebamiento, como es el caso de Martín de Todos los Santos (Causa criminal por querella de Agustín Capcha contra Martín de Todos los Santos y María Magdalena, indios del pueblo de Amabar, por estar amancebados, AAL, Causa de Amancebamiento, leg. 5, exp 34, Ambar 1662, o en los documentos transcriptos en García Cabrera, 1994).

19 Causa contra don Rodríguez Pilco, cacique y gobernador del pueblo de Ambar, por haber permitido a un yndio el hacer un simulacro de misa y de bautismo en la fiesta del Corpus, AAL, Hechicerías e Idolatrías, leg. IIA, exp. 12, Ambar 1661/1662, f. 210r. 
parte de los feligreses y podrá repetirse en otra fiesta mayor, ya que, como consta en el testimonio de Juan Culca, «el dho cura no solo no las prohiuio [a las ceremonias] antes las aplaudio riendose y celebrandolas y diciendo a los yndios ver a su buestro cura oyrle la misa y que por esta causa se atrevieron los yndios a bolber hacer» ${ }^{20}$.

El aval del doctrinero funciona aquí como aliciente y aprobación del juego ritual. El cura testigo, permite y aplaude el rito idolátrico, y por medio de los testimonios promovidos por Rodríguez Pilco, se lo implica intencionalmente en el mismo. Si bien no ocurre nada en ese momento - no hay denuncias al respecto-, traer estos hechos a colación en medio del escándalo del Corpus supone involucrar al cura y presentar un antecedente importantísimo para el caso. Rodríguez Pilco utiliza la fiesta de la Candelaria como excusa para esta reactualización de los hechos, y acusar al cura de manera fehaciente al haber un historial permisivo. Nos encontramos entonces ante una manipulación de lo sagrado que funciona en muchos casos como herramienta de poder en el mantenimiento de las autoridades tradicionales ${ }^{21}$, como veremos a continuación, puesto que ambos, cura y curaca, serán capaces de sostener un accionar de acuerdo con sus propios intereses.

Al mismo tiempo, es importante notar que estos acontecimientos se dieron en medio de un historial de acusaciones cruzadas entre ambos representantes de la autoridad, puesto que, como se desprende de los testimonios, era vox populi que Rodríguez Pilco quería capitular al cura, y Salazar de Montesinos desacreditar al curaca y quitarlo del gobierno, lo que se hará explícito en varios momentos del juicio. Salazar Montesinos promete destituir a don Juan Rodríguez Pilco y encumbrar en su lugar a uno de los hermanos relegados del cacique, Pablo Quispe Pilco, resentido por no haber sido elegido Persona Principal en lugar de don Juan de Albarado ${ }^{22}$. Don Pablo apoya la posición

${ }^{20}$ Ibidem, f. 221r, énfasis agregado.

${ }^{21}$ Millones, 1978: 108 .

22 Pablo Quispe Pilco es hijo bastardo de don Gaspar Rodríguez Pilco y es probable que su madre sea Isabel Canchan, una india acusada de hechicera y concubina del mismo don Gaspar (Causa seguida por don Cristobal Chaupiguaranga, Juan Huaman, Alonso de Heredia, Martín Naupari, Juan Martín, Francisco Ringri, caciques principales de este repartimiento, contra el capitán Gaspar Rodriguez Pilco, cacique principal, sobre los bienes de la Iglesia, AAL, leg. 17, exp. 10, Ambar 1657, 58 ff.), quien fuera el anterior curaca de Ambar y padre de don Juan, Pablo Quispe y Juan de Albarado, mientras que éste último no solo es hermano de padre, sino también de madre de don Juan (Causa contra don Rodríguez Pilco, cacique y gobernador del pueblo de Ambar, por haber permitido a un yndio el hacer un simulacro de misa y de bautismo en la fiesta del Corpus, AAL, Hechicerías e Idolatrías, leg. IIA, exp. 12, Ambar 1661/1662, ff. 281 y ss.). Por otro lado, también tenemos noticias de don Pablo que lo involucran en un caso de idolatría en el marco de la causa contra Juana Maugay. Agustín 
de Salazar Montesinos en un intento de despojar de su cargo a sus dos hermanos, don Juan, el curaca, y don Juan de Albarado, segunda persona ${ }^{23}$. Si atendemos a las causas actuadas en estos años en Ambar, nos encontraremos con buena parte del pueblo involucrado en esta serie de pleitos cruzados que de alguna manera ilustran la trama cotidiana y las relaciones interpersonales y familiares de una comunidad donde el poder curacal es relativamente inestable, y la manipulación del aparato judicial en función de intereses personales parece ser moneda corriente ${ }^{24}$.

\section{Pleitos y CAPÍtulos: EL INDIO DENUNCIANTE Y EL CURA PERMisivo}

Uno de los aspectos que interesan en casos como el que nos ocupa tiene que ver con los numerosos conflictos entre los doctrineros y los curacas, que encontramos salpicados a lo largo de los fondos documentales y que nos permiten reconstruir un momento crucial de las relaciones coloniale ${ }^{25}$. Éstos ocurren muchas veces acaecidos por disputas por el poder simbólico que el nuevo régimen arrebata al curaca, quien aspira a retener o reconquistar un prestigio religioso que ahora posee el sacerdote por la naturaleza misma de

Capcha, actuando como fiscal mayor, lo acusa ante el visitador Sarmiento de Vivero de, en calidad de mayordomo de la cofradía del Santísimo Sacramento, haber permitido llevar a cabo danzas rituales catalogadas de idolátricas durante las celebraciones del Corpus Christi de 1622, (Causas criminales de idolatrias y hechicerías contra unas indias de la doctrina de Ambar, AAL, Hechicerías e Idolatrías, leg. 4, exp 2, Ambar 1662). García Cabrera, 1994 recoge esta causa como parte de una compleja red de acusaciones y denuncias llevadas a cabo en la doctrina de Ambar y que tienen como protagonista a Agustín Capcha, investido en su nuevo rol de fiscal mayor, deber que conlleva el «no consentir nengon pecado publico escandalo contra la ley de Dios como son hechiseros ydolatras y casados dos beses y concubinarios y amansebamintos» (García Cabrera, 1994: 393).

${ }_{23}$ Causas criminales de idolatrías y hechicerías contra unas indias de la doctrina de Ambar, AAL, Hechicerías e Idolatrías, leg. 4, exp 2, Ambar 1662, ff. 281v-282r. Véase también los expedientes recopilados por García Cabrera, 1994 donde se menciona a Pablo Rodríguez Pilco, la mayoría de las veces actuando como alcalde ordinario, señal de que Capcha no es el único que medra a partir de estos eventos.

24 Sobre la manipulación jurídica y la movilidad socioeconómica de los indígenas en el Perú, véase Spalding, 1973; 1974.

25 Sobre la cultura legal entre los indígenas en los Andes hay una numerosa bibliografía. Véase Honores, 2006; 1999; 1993. Dueñas, 2015. Aguirre, 2012. Puente Luna, 2015; 2007. Poloni-Simard, 2005. Pease, 1995, entre otros muchos, y la excelente antología preparada por Zaballa Beascoechea, 2001. Esta bibliografía selecta da una buena idea de lo que estaba sucediendo en el Perú en relación con los pleitos, abogados, litigios, acusados y acusadores, siempre teniendo en cuenta que al menos uno de los interesados era indígena. 
su cargo ${ }^{26}$. El curaca, personaje muchas veces ambiguo y acomodaticio, conserva algún grado de poder, restaurado por la autoridad colonial luego de la caída del Incario ${ }^{27}$, pero se ve obligado a compartir su autoridad con el fraile doctrinero, un nuevo personaje que desestabiliza el equilibrio del poder dentro de la comunidad. A su vez, el doctrinero es una pieza clave en el contexto local de las denuncias, donde sus intereses y autoridad son fundamentales a la hora de pactar con sus feligreses, como intenta hacer Salazar Montesinos al ocultar los sucesos del Corpus durante tres meses, o denunciar a sus curacas en función de sus asuntos económicos o de poder ${ }^{28}$.

Recordemos que los doctrineros son sometidos al control procesal no solo por incumplimiento de sus deberes sacerdotales, como indica García Cabrera, sino también en lo que atañe a la explotación, granjerías y maltrato, puesto que muchos doctrineros — para la época del arzobispo Arias y Ugarte habría unos trescientos curas desocupados - recurrían a cuanto medio tenían a su alcance no solo para enriquecerse, sino incluso para sobrevivir. El arzobispo Villagómez hace hincapié en la codicia de los curas a la hora de delinear los males que aquejan a las doctrinas ${ }^{29}$. Esta situación hacía que la situación política de los mismos fuera endeble en relación con sus propios feligreses, quienes se quejaban de la falta de idoneidad de los curas de indios, los maltratos perpetrados para con los naturales, la explotación económica a la que se veían sometidos, etc. Otro dato a tener en cuenta es la obligación de los curas de denunciar borracheras o el uso indebido de la chicha, bebida que

${ }^{26}$ Rowe sostiene que para el año 1754 hay unos 2070 caciques en el virreinato del Perú (1957: 157). Pease comenta que con la colonia cambia la situación legal de los curacas, ya que se convierten en cargos hereditarios, con las condiciones feudales que esto conllevaba. El historiador atribuye esta condición feudal, que no era vista como un peligro por la administración española, a cierta «aparición de una conciencia de clase señorial entre los curacas a partir del siglo XVI, que duró hasta el siglo XVIII. Asumieron, así, las autoridades étnicas... un status de privilegio que mantener, en tanto que caciques nombrados, por herencia y señorío, como también en tanto nobleza de aquellos que se reclamaban descendientes de los incas cuzqueños y llevaron adelante largos y costosos procedimientos judiciales para establecer su ascendencia legítima (desde el punto de vista de la legislación española), y sus derechos reconocidos por la misma administración colonial» (1991: 129). La situación del curaca es de gran inestabilidad en estos momentos, tal como analiza José Carlos de la Puente Luna, 2007, en especial en el capítulo 4, donde se estudia el poder curacal en función de las reglas de sucesión impuestas por la Corona. Sobre la doble legitimidad del curaca en relación con su comunidad, véase Ramírez, 1987.

27 Espinosa Soriano, 1960: 189 y ss.

${ }^{28}$ Puente Luna, 2007: 180.

29 «... que es mayor la culpa del cura, que por la codicia se imposibilita de hacer como debe su oficio de ministro del Dios verdadero, y se hace sacerdote de Dagón en ser idólatra del dinero» (Villagómez, 1664: 68). 
frecuentemente era utilizada en idolatrías y supersticiones ${ }^{30}$, y en el caso de Ambar, cuando Salazar de Montesinos se retiró a sus actividades privadas debe haber advertido el estado de ebriedad de sus feligreses y falló en denunciarlos. A eso se suma la utilización de la chicha supliendo el vino consagrado en la falsa celebración de la misa.

Por su parte, los curacas no eran ajenos al uso del sistema judicial a la hora de defender sus posiciones e intereses, tanto personales como comunitarios. Conviene aquí, a los fines de mejor entendimiento de los sucesos de Ambar y la posición política de sus protagonistas, hacer un alto y profundizar en las acciones legales llevadas a cabo por la familia Rodríguez Pilco. Don Juan litiga contra el sacerdote Diego de Alva, doctrinero que se desempeñaba en Ambar antes que Salazar Montesinos, a quien querella por quitarle el sombrero de la cabeza y arrojado al suelo, insultarle llamándole «perro borracho», amenazarle con un castigo físico y expulsarle del pueblo. Rodríguez Pilco acusa al cura de faltarle el respeto «porque siendo cacique principal y gobernador y persona notable me trato como a plebeyo afrentandome con palabras tan infames y grabes en que nunca e incorrido ${ }^{31}$. También se presenta en un pleito de capítulos contra el doctrinero Salazar de Montesinos anterior a los sucesos del Corpus en el cual ha ganado una provisión para que no se le diese mita de indios y pagara el camarico que adeudaba, mencionada por don Juan en varios momentos del caso que nos ocupa ${ }^{32}$ para demostrar que la enemistad de Salazar Montesinos para con su persona es de larga data.

30 Tanto los Sínodos de Yungay (1585) como los de Lima de 1602 y 1604 se hacen eco de la prohibición de venta y distribución de chicha y otros alcoholes como el aguardiente entre los indios. Es deber del doctrinero reforzar las disposiciones sinodales, puesto que «siendo este vicio en los Indios muy general, y fuente y raíz de otros muchos y gravísimos pecados: y el principal impedimento que hay para su Christiandad y para fruto del Santo Evangelio, que se les predica» (Constituciones sinodales..., 1987: 263-264).

${ }_{31}$ Causa seguida por don Cristobal Chaupiguaranga, Juan Huaman, Alonso de Heredia, Martín Naupari, Juan Martín, Francisco Ringri, caciques principales de este repartimiento, contra el capitán Gaspar Rodriguez Pilco, cacique principal, sobre los bienes de la Iglesia, AAL, leg.17, exp.10, Ambar 1657, f. 41r y Causa seguida por los caciques y gobernadores de las doctrinas de San Luis de Huari, Chacas, Lima, Ambar, Llata y Asco, don Fernando de Vega, Gaspar de Loayza, Juan Rodriguez Pilco, Elvira Ortiz, Marcos García Ricopa y Sebastián Yamacondor, contra los curas José de Utrilla Velazco, Gerónimo Hurtado, Diego Gonzalez de Alva, Bernardo de Salazar, Rodrigo de Medina y Bernardo de Amolea, AAL, leg. 17, exp. 15, 1658-1661, $61 \mathrm{ff}$.

${ }^{32}$ Causa contra don Rodríguez Pilco, cacique y gobernador del pueblo de Ambar, por haber permitido a un yndio el hacer un simulacro de misa y de bautismo en la fiesta del Corpus, AAL, Hechicerías e Idolatrías, leg. IIA, exp. 12, Ambar 1661/1662, ff. 208v, $254 \mathrm{r}$, etc. 
Rodríguez Pilco querella al visitador Sarmiento de Vivero, acusándolo de mantener presos a algunos indios que se negaban a declarar en contra de su curaca, de demorarse en la inspección de las cofradías y de que los oficiales que lo acompañaban se apropiaban de los bienes de los feligreses. En 1662 instruye a Don Francisco Bilcaguaranga, Alonso Xulca Cóndor, Lázaro Guari Guamán, y Don Joseph Guaranga, alcaldes ordinarios y camachicos del pueblo, para que acudan al arzobispo Villagómez, soliciten la destitución del visitador y nombrar en su lugar a «alguien celoso de la onra de Dios Nuestro Señor y que sea lenguaraz $\rangle^{33}$. Los naturales aducían que Sarmiento de Vivero se tomaba más tiempo del adecuado en las visitas ${ }^{34}$, se apropiaba de los bienes de los feligreses y lo acusan además, — esta es la imputación más grave que ponen los indios y que involucra directamente al curaca - de mantener presos a Domingo Guaman Huari, Martín de Todos los Santos y Alonso de Todos los Santos por no haber declarado en la causa contra Rodríguez Pilco ${ }^{35}$, fabricando cargos de idolatría y amancebamiento para éstos y castigándolos con prisión, tortura y posterior trasquilamiento ${ }^{36}$. El arzobispo, por su parte, envió en comisión investigadora a Pedro Ruiz de Garfias, cura beneficiario y vicario de Huaura. No se conserva el resultado de tal investigación, pero colegimos que si Villagómez despacha una comisión en contra del visitador es porque su conducta y fama le preceden. Por otro lado, el hostigamiento e intento de provocar falsos testimonios en favor de los doctrineros era una práctica bastante común entre los visitadores, a juzgar por los casos que analiza Nicholas Robins ${ }^{37}$.

${ }^{33}$ Autos que siguen los alcaldes ordinarios contra el licenciado Juan Sarmiento de Vivero, sobre las vejaciones que padecen los indígenas, AAL, Visitas, leg. 11, exp. 33, Ambar 1662 , f. $1 \mathrm{v}$.

${ }^{34}$ Sarmiento de Vivero es un visitador polémico. Hay numerosas causas en su contra, como se puede deducir examinando los catálogos del Archivo Arzobispal (Gutierrez Arbulú, 1993. Tineo Morón, 1992; 2016), algunas de ellas mencionadas supra en la nota 14.

${ }^{35}$ «Y las dhas priçiones y bejaziones es solo por uengar por este medio la paçion y odio que les tiene a estos miserables porque no juraron y conspiraron que Don Juan Rgs Pilco gouern. or del dho repartim.to lo que les dicto el dho visitador y cura Lido Juan de Salazar», Autos que siguen los alcaldes ordinarios contra el licenciado Juan Sarmiento de Vivero, sobre las vejaciones que padecen los indigenas, AAL, Visitas, leg. 11, exp. 33, Ambar 1662, ff 1r-v.

${ }_{36}$ El trasquilamiento era un castigo frecuentemente utilizado para con los indígenas, y consistía en cortarles el cabello de manera burda, sin forma, mal cortado. Se consideraba una deshonra tener que aparecer en púbico con el cabello en tales condiciones. En el documento que nos ocupa (Causa contra don Rodríguez Pilco, cacique y gobernador del pueblo de Ambar, por haber permitido a un yndio el hacer un simulacro de misa y de bautismo en la fiesta del Corpus, AAL, Hechicerías e Idolatrías, leg. IIA, exp. 12, Ambar 1661/662), la amenaza de trasquilamiento aparece al menos cuatro veces (ff. 77v, 92r, 92v, 97v).

37 Robins, 2009: 124. 
Don Gaspar, padre de don Juan, también es objeto de demanda de sus propios indios por mal manejo de los bienes eclesiásticos y uso indebido del trabajo de la comunidad en una causa de $1657^{38}$. Se lo imputa también, como ya señalamos, de amancebamiento con Isabel Canchan, quien era sospechada de hechicera ${ }^{39}$. Esta causa aparece mencionada en el caso que nos ocupa, en el marco de una petición que hacen once indios firmantes en contra de los Rodríguez Pilco, avalando la posición del licenciado Juan de Salazar Montesinos fechada el 14 de septiembre de $1657^{40}$. Los mismos firmantes recuerdan los falsos pleitos que don Gaspar les iniciara a dos curas doctrineros que oficiaban en Ambar durante su curacazgo, el maestro Juan Gonzalez de Oserin y el licenciado Jacinto de Quesada, quienes, para defenderse de las calumnias, fueron forzados a «gastar su hasienda en defenderse de los capítulos que les ponía por nosotros este mal xpiano» ${ }^{41}$.

Para comprender lo complejo de una sociedad y de un grupo humano como el que estamos analizando, resulta crucial hurgar en historias singulares, y para ello, leer los documentos que tenemos a nuestra disposición, no solo los publicados, como en el caso de García Cabrera o Rivarola, en relación con la doctrina de Ambar, sino también identificando otros expedientes en los archivos. Como vemos a partir de la lectura de los documentos aquí estudiados, lo judicial envuelve a la sociedad colonial en todos sus estratos, y la familia Rodríguez Pilco tiene fama de pleitista. Tanto don Juan como su padre y hermanos son viejos conocedores del sistema legal virreinal, y lo utilizan activamente. Con su accionar, dan cuenta de un reconocimiento tácito de su

38 «Y las dhas priçiones y bejaziones es solo por uengar por este medio la paçion y odio que les tiene a estos miserables porque no juraron y conspiraron que Don Juan Rgs Pilco gouern.or del dho repartim.to lo que les dicto el dho visitador y cura Lido Juan de Salazar» (Causa contra don Rodríguez Pilco, cacique y gobernador del pueblo de Ambar, por haber permitido a un yndio el hacer un simulacro de misa y de bautismo en la fiesta del Corpus, AAL, Hechicerías e Idolatrías, leg. IIA, exp. 12, Ambar 1661/1662, f. 236v). Sobre los principios de reciprocidad en el curacazgo, y también su relación con los encomenderos y doctrineros, la bibliografía es amplísima, pero recomendamos revisar los estudios de Pease, 1995 en especial el capítulo IV, Spalding, 2002; 1991; 1973. Alaperrine-Bouyer, 2005. Assadourian Sempat, 1994, para tener una imagen global y general del estado de la cuestión.

${ }_{39}$ Causa seguida por don Cristobal Chaupiguaranga, Juan Huaman, Alonso de Heredia, Martín Naupari, Juan Martín, Francisco Ringri, caciques principales de este repartimiento, contra el capitán Gaspar Rodriguez Pilco, cacique principal, sobre los bienes de la Iglesia, AAL, leg.17, exp.10, Ambar 1657, 58 ff.

40 Causa contra don Rodríguez Pilco, cacique y gobernador del pueblo de Ambar, por haber permitido a un yndio el hacer un simulacro de misa y de bautismo en la fiesta del Corpus, AAL, Hechicerías e Idolatrías, leg. IIA, exp. 12, Ambar 1661/1662, ff. 263r-265r.

${ }^{41}$ Ibidem, f. $246 \mathrm{r}$. 
parte al sistema de dominación en el cual se encuentran inmersos y que intentan manipular a su favor.

Así, el curaca busca reconocimiento de su autoridad operando en un sistema legal que a veces termina fallándole, como ocurre en nuestro caso, ya que el doctrinero sigue en la misma doctrina o en otra, pero no se lo expulsa del sistema. Como estudiamos, los litigios surgen a partir de fricciones intracomunitarias, quejas de los indios por aranceles y exacciones, desdén del cura, poco conocimiento de la lengua para predicar y confesar, negligencia en la aplicación de los Sacramentos, o directamente por confrontaciones entre el clérigo y el curaca, que pueden tener múltiples motivos, desde económicos hasta de carácter religioso, referidos a la fidelidad o no con la que el cura lleva a cabo su misión ${ }^{42}$. Al mismo tiempo, el litigio se permite a los indios, puesto que funciona, de alguna manera, como «barómetro de tensiones sociales $\rangle^{43}$ útil a la corona: legitima el poder judicial colonial y apacigua las tensiones producidas en el seno de las comunidades indígenas. En otras palabras, el curaca hace uso tanto de lo legal como de la ciudad letrada que describiera Ángel Rama manipulando un sistema, jugando con la viabilidad o no del recurso judicial según el caso, pero teniendo en cuenta la opción del litigio como horizonte. Si «discutir sobre la legitimidad de los señores étnicos coloniales es hacer referencia, en buena medida, a los mecanismos de acceso al poder ${ }^{44}$, también lo es en relación con el sostenimiento de este poder a través de altercados entre los distintos actores sociales.

Cura y curaca se ven compelidos a utilizar un mismo sistema legal -el virreinal - para resolver estas disputas, y cada uno de ellos posee un conjunto de herramientas desprendidas de sus respectivos cargos: el cura utilizará causas por idolatría contra sus feligreses «mal encarados»; en querellas de los indios contra sus doctrineros, se verán enfrentados en causas de capítulos. Tanto las acusaciones de idolatría como los capítulos se convertirán con el tiempo en algo regular, casi rutinario al no tratarse de nada nuevo. En el caso que nos interesa, sabiendo por experiencia propia de esta ineficacia de los capítulos, don Juan Rodríguez Pilco intentará montar un escándalo de proporciones para evitar los capítulos e involucrar al cura utilizando como antecedente «permisivo» el caso de la Candelaria, una muy astuta manipulación del sistema y la situación.

${ }^{42}$ Hay numerosos casos de indios que denuncian a sus curas por «faltas a la ortodoxia» o por hacer la vista gorda ante rituales evidentemente idolátricos. Véase, por ejemplo, los casos consignados por Estenssoro Fuchs, 2003: 145 y ss. Lavallé, 1982. Charles, 2010.

${ }^{43}$ Puente Luna, 2007: 203.

${ }^{44}$ Robins, 2009: 103. 


\section{LA IMPORTANCIA DE SER BUEN CRISTIANO}

Una de las hipótesis que manejamos y que se desprende de una cuidadosa lectura del expediente, en particular del Memorial de Tachas en el cual el curaca intenta delinear su «persona» pública por medio de testimonios favorables, es que éste se propone "ser más indio», suponiendo que al enfatizar el escándalo para provocar la remoción del cura, permanecerá ajeno al fuero inquisitorial, que sí ha de caer sobre el doctrinero. Sin embargo, el curaca parece obliterar el hecho de que los naturales, en lo referido a delitos de idolatrías y apostasías, estaban sometidos a los visitadores eclesiásticos, previsto esto desde el Tercer Concilio Limense (1583-91). El indio litigante no necesita conocer todos los vericuetos del sistema jurídico colonial, sino poseer determinado manejo de un discurso y razonamiento legal básico que le permitan maniobrar por entre los meandros de la justicia ${ }^{45}$, y a la vez hacer pie en un sistema jurídico de relativa ambivalencia en lo que respecta a la figura del indio: por un lado, su misma condición de «miserabilidad» ${ }^{46}$, y por otro, el hecho de decirse indio, establecerse como tal y gozar de las prerrogativas que ello conlleva.

Pero para lograr esto hay primero que ser un buen indio o, en palabras de Estenssoro Fuchs, «reclamarse indio ${ }^{47}$. Como analizamos con anterioridad, en el interrogatorio de probanzas a favor de Rodríguez Pilco, fechado y aprobado en julio de $1663^{48}$, se pregunta detalladamente a una serie de testigos presentados por él mismo acerca de lo acaecido durante la fiesta del Corpus (preguntas 1 a 7), así como también por los sucesos de la Candelaria (pregunta 8), la relación de enemistad entre el cura y el doctrinero (preguntas 9 a 11), incluyendo dádivas y amenazas que pudo haber ofrecido éste último para obtener testimonios propicios, y respecto de la calidad de buen cristiano de Rodríguez Pilco (pregunta 12) ${ }^{49}$. Las respuestas son todas favorables al cura-

45 Charles, 2011: 209.

46 Solórzano Pereira, 1972, define esta condición en los capítulos 28 («Que los indios son y deben ser contados entre las personas que el Derecho llama miserables, y de qué privilegios temporales gocen por esta causa, y de sus protectores») y 29 («De los privilegios y gracias que a los indios por miserables y recién convertidos, les están concedidas en las causas y materias espirituales») del Libro II de la Política Indiana.

47 Estenssoro Fuchs, 2003.

${ }^{48}$ Causa contra don Rodríguez Pilco, cacique y gobernador del pueblo de Ambar, por haber permitido a un yndio el hacer un simulacro de misa y de bautismo en la fiesta del Corpus, AAL, Hechicerías e Idolatrías, leg. IIA, exp. 12, Ambar 1661/1662, ff. 205r a 209r.

${ }^{49}$ Nos enteramos así de que don Juan fue mayordomo de la iglesia, es buen cristiano, paga cera y pebetes de su bolsillo, cuida de que los indios asistan a misa y a la doctrina los miércoles, viernes y domingos. Leemos aquí una fuerte negociación producida dentro de la comunidad con el objeto de apoyar a un sector determinado (el del curaca), en menoscabo de 
ca. Como tal, éste debe acentuar su condición de indio cristiano por medio de su participación en las fiestas de la Iglesia, sobre todo las importantes como el Corpus, ya que en ellas «los indígenas cristianizados - en particular las elites - definían (y defendían) su posición dentro de la sociedad colonial y reconstruían su identidad adaptándolas a las nuevas circunstancias coloniales $\rangle^{50}$, por lo que la impostación de su actuación cobra relevancia en función de la relación con un doctrinero permisivo y negligente.

Rodríguez Pilco construye su identidad de buen cristiano y celoso de la religión en contraposición de la del doctrinero, un cura que permite - ipor temor? - la concreción de ceremonias idolátricas como la mencionada durante la fiesta de la Candelaria ${ }^{51}$, o que abandona a su feligresía una vez acabada la misa del Corpus para atender sus asuntos personales. Ser buen cristiano para un indígena significa ser comisario de la fe, delatar idolatrías pero también cuidar de que el cura se pliegue a la ortodoxia y no sea excesivamente permisivo con sus feligreses. Esta obligación del curaca se hace extensiva a indios principales, alguaciles y fiscales. Asimismo, sabemos que el acto de delación sirve como atenuante de la idolatría, en tanto que la demora en la denuncia es un factor que incide en las penas impuestas ${ }^{52}$. Recordemos que Salazar Montesinos no denuncia la idolatría inmediatamente, sino que intenta negociar la amenaza de capítulos con Rodríguez Pilco. Al no lograrlo y siendo el escándalo del Corpus vox populi, no le queda más remedio que contar los sucesos de Ambar en el marco de la visita de Sarmiento de Vivero, dando comienzo así al pleito ${ }^{53}$. La delación era obligatoria bajo duras penas espirituales, y Salazar Montesinos incurre en delito al dilatar la denuncia.

la figura del doctrinero, quien también cuenta con un grupo de indios que actúa a su favor, en muchos casos, producto de una mala relación con Rodríguez Pilco. Esta mala relación llega a ser de carácter personal, como el ya mencionado testimonio de Pedro Quispe Pilco, el despechado hermano del curaca, en una serie de pleitos cruzados e intereses políticos y económicos que se ponen de manifiesto en los años que dura esta causa.

50 Stanic, 2013: 368.

${ }^{51}$ El temor a los indios capitulantes está presente a lo largo de todo el virreinato. De hecho, el cura interino de Ambar, Bernabé López Burgos, duda de denunciar otros episodios idolátricos ocurridos durante el Corpus Christi del año siguiente, «no sea cosa que me levanten algún testimonio» (Causas criminales de idolatrías y hechicerías contra unas indias de la doctrina de Ambar, AAL, Hechicerías e Idolatrías, leg. 4, exp. 2, Ambar 1662. García Cabrera, 1994: 397).

${ }^{52}$ En ámbitos inquisitoriales el hecho de denunciarse a sí mismo siempre fue considerado como aliciente, y era muy frecuente, ya que el reo recibía mejores condiciones carcelarias y hasta una sentencia más benigna. Sobre el tema, véase Millar Carvacho, 1998: 286.

${ }_{53}$ Sin embargo, no hay que olvidar que para que comience un pleito no tiene que haber necesariamente una denuncia formal, puesto que puede iniciarse de oficio en el marco de una 
«Ser indio», en estas circunstancias, implica manifestarse como culturalmente católico, habitar una cultura con parámetros católicos, donde la ortodoxia y la observancia sean importantes, y formar parte de un mismo mundo de creencias y prácticas religiosas concretas en las que haya lugar para determinados grados de heterodoxia y transgresión amparados y atenuados por su misma condición de neófitos, cristianos nuevos y miserables. A este nivel funcionan determinadas dinámicas de la identidad que implican obligaciones y posibilidades, según la estructura colonial en la que se acoja. Por ende, la identidad no es un hecho ontológico en sí, sino una performance que tiene lugar a través de la vida legal y discursiva de las personas. Es decir, la identidad, en especial la identidad de sujetos coloniales atravesados por contradicciones y reestructuraciones, toma forma a través de la participación del individuo en determinados contextos de ritos colectivos, ya sean sociales, culturales, religiosos, aspectos todos difíciles de separar en la vida colonial, a la vez que se presenta como una abstracción con sus consiguientes límites.

El curaca, miembro de una elite reacomodada a los cánones coloniales, debe ser un sujeto ejemplar, una nueva encarnación de la virtud cristiana, y seguir manteniendo cierta autoridad religiosa en su comunidad, pero con un cambio de signo, muchas veces demostrando que es mejor cristiano que el cura. En el caso estudiado, Salazar Montesinos luego de la misa se va a su finca a atender sus negocios personales, mientras que Rodríguez Pilco parece encarnar la figura del guardián de la fe. Es él quien castiga la supuesta idolatría de Agustín Capcha. Es también quien obliga a los indios a ir a la doctrina los miércoles y domingos, según se desprende del Memorial de Tachas, pretende un nuevo sacristán, más «limpio» y adecuado para la comunidad, y quien denuncia que el cura utiliza mano de obra indígena para sus tratos y granjerías sin importarle la asistencia a la misa ni las obligaciones espirituales de sus feligreses ${ }^{54}$. Es también capaz de exhibir numerosos testimonios que atestiguan su cualidad de buen cristiano, respetuoso de las leyes divinas, en contraposición con el doctrinero, quien cuenta sobre sus espaldas con el deshonroso antecedente de la fiesta de la Candelaria.

Con su prestigio y autoridad en juego, el curaca navega entre dos aguas: por un lado, como representante de su comunidad, y por el otro, como guardián y garantía del nuevo orden en tanto que se reposiciona política y econó-

visita, y Sarmiento de Vivero estaba visitando la provincia de Cajatambo, por lo cual, el desencadenamiento de los eventos no era más que una cuestión de tiempo.

${ }^{54}$ Causa contra don Rodríguez Pilco, cacique y gobernador del pueblo de Ambar, por haber permitido a un yndio el hacer un simulacro de misa y de bautismo en la fiesta del Corpus, AAL, Hechicerías e Idolatrías, leg. IIA, exp. 12, Ambar 1661/1662, ff. 277r a 299v. 
micamente. Debe resguardar los valores andinos, pero al mismo tiempo, ser un buen cristiano. A su manera, Rodríguez Pilco será capaz de asimilar los mecanismos necesarios para ingresar en el juego del poder y defenderse en los resquicios legales que le permite la justicia virreinal.

El control del poder depende, en buena medida, de la identidad, conciencia y conocimiento del sujeto que pone en movimiento el engranaje judicial. ¿Qué pasa cuando el indio "se sabe indio» y para ganar espacios de poder no hace más que reafirmar su condición de subalternidad? ${ }^{55}$ Rodríguez Pilco declara que la Inquisición no tiene jurisdicción sobre su persona, aunque sí la tiene la justicia eclesiástica. Ser indio implica una serie de privilegios y de obligaciones enmarcadas en una definición profundamente ideológica, «jurídico-fiscal en su base y étnico-religiosa en su justificación ${ }^{56}{ }^{5}$ : exención del fuero inquisitorial y ayunos menos rigurosos, asistencia obligatoria al catecismo los miércoles, viernes y domingos, pero también determinadas restricciones a los sacramentos ${ }^{57}$. Al mismo tiempo se elabora una doble identidad del indio: el idólatra, que sirve como mecanismo de control de extirpación y evangelización por parte del clero, y el «buen» cristiano, que a su vez controla al clero en su accionar, un «indio convertido, sincero, devoto e incluso más fiel a la religión y a sus reglas morales que el promedio de los españoles $\rangle^{58}$.

En este marco, solo los indios cristianos permanecerán dentro de la sociedad, los idólatras quedarán fuera del cuerpo social, y deben ser castigados. Ser indio cristiano, participar de la ambivalencia de ser uno y otro, deviene en arma defensiva para jugar en el campo del poder colonial. Implica asimismo saber jugar las cartas legales del otro para mantener un lugar propio, apropiado y asignado en el poder colonial. Este indio virtuoso puede posicionarse dentro del espacio sagrado y permanecer cerca del cura para ser reconocido y legitimado, haciendo de la Iglesia su casa. Para ejercer la virtud, el indio requiere de un sostén institucional donde pueda denunciar idolatría y vigilar a sus congéneres, tal como establecen Lobo Guerrero (1617) y el arzobispo Villagómez $(1649)^{59}$. El indio virtuoso — mote que en este momento

55 Cabe aclarar que cuando hablamos de «subalternidad» en el caso de Rodríguez Pilco nos referimos a su condición de natural respecto de los españoles, y no en relación a su clase $\mathrm{u}$ oficio curacal.

56 Estenssoro Fuchs, 2003: 441.

57 Ibidem: 430.

58 Ibidem: 441.

59 Bartolomé Lobo Guerrero firma un auto fechado el 30 de agosto de 1617 donde consta el deber de los indios de denunciar idolatrías, así como también los premios y castigos a infractores y cómplices. Pedro de Villagómez hace hincapié en lo mismo en su Carta Pastoral de 1649 . 
correspondería no al curaca sino al sacristán, guardián de la ortodoxia, ahijado del cura y quien da fin a la ceremonia idolátrica-, pone en riesgo su identidad étnica, se convierte en mal indio, pierde el respaldo de su comunidad y es agredido.

En estas circunstancias, nos encontramos ante un indio cristiano, cuidadosamente delineado a lo largo de los numerosos interrogatorios, versus un cura negligente y temeroso de capítulos, punto débil del proyecto de extirpación ${ }^{60}$, en un contexto político en el cual los elementos religiosos y económicos, sociales y de poder, se patentizan en ambas figuras. La jugada de Rodríguez Pilco parece bastante clara: por un lado, como señor natural de su comunidad, se apropia del poder político y funge como guardián de las buenas costumbres y funcionamiento cotidiano, y por el otro, usa de la lengua y de la Iglesia como fuente de legitimidad de su propio poder esgrimido contra la autoridad religiosa, el doctrinero. Y es este último aspecto el que puede darle la carta ganadora. El curaca, al apropiarse del discurso eclesiástico, no hace más que asegurar para sí una noción de orden cristiano que explota en función de su cualidad de jefe político. Apoyarse en la autoridad que le confiere el hecho de ser buen cristiano le permite dejar en evidencia a Salazar Montesinos y de ese modo intentar un alivio a sus culpas.

En contrapartida el licenciado Salazar de Montesinos es presentado, por momentos, como un cura temeroso y enemigo del curaca, con quien mantiene incluso un pleito económico en relación a la provisión para que le quitasen indios de mita que mencionamos con anterioridad. Pedro de la Cruz, cantor de oficio, alega haber sido testigo de la mala voluntad de Salazar Montesinos en contra de Rodríguez Pilco, quien había dicho en público que «le auia de quitar el gouierno y destruirlo y lo sabe por auerselo oydo decir al dho cura» ${ }^{61}$. Además, es acusado de ofrecer dineros, dádivas, amenazas y persuasiones a los indios para que testifiquen en contra del curaca ${ }^{62}$. En suma, nos encontramos aquí ante una guerra abierta entre doctrinero y curaca, en la cual uno intenta desacreditar al otro durante el proceso judicial que involucra una cantidad de testigos y tachas de ambos lados y cuya valía se disputa en función de la calidad de los testigos presentados.

${ }^{60}$ García Cabrera, 1994: 59.

${ }^{61}$ Causa contra don Rodríguez Pilco, cacique y gobernador del pueblo de Ambar, por haber permitido a un yndio el hacer un simulacro de misa y de bautismo en la fiesta del Corpus, AAL, Hechicerías e Idolatrías, leg. IIA, exp. 12, Ambar 1661/1662, f. 215r.

${ }_{62}$ Causa contra don Rodríguez Pilco, cacique y gobernador del pueblo de Ambar, por haber permitido a un yndio el hacer un simulacro de misa y de bautismo en la fiesta del Corpus, AAL, Hechicerías e Idolatrías, leg. IIA, exp. 12, Ambar 1661/1662, f. 205r. 
Esta permanente amenaza de capítulos y pleitos entre autoridades resulta ser un recurso válido por parte de los indios para establecer una identidad parcialmente impuesta por la colonia, es decir, encuadrar identidades sociales construidas tanto dentro de la ideología colonial como en sus márgenes. Se plantearía así una doble agenda de parte de los indios pleitistas que podemos vislumbrar en nuestro expediente: por un lado, el deseo de deshacerse del doctrinero, pero por el otro, reconfigurar relaciones de poder internas a la comunidad desplazando al sacristán o incluso jugando dentro de un sistema de parentesco y establecimiento del curacazgo que no necesariamente satisface a todos los participantes de la contienda. Consecuentemente, se trata de equilibrar los espacios de poder y la vida política en una comunidad en la cual el doctrinero suele actuar como verdadero jefe local y el curaca pretende retener un prestigio político y religioso diluido o directamente arrebatado por la autoridad religiosa. En suma, negociar la calidad de indio y buen cristiano y los fueros legales que ello conlleva, es decir, constituirse como 'miserables' para accionar desde dentro del sistema legal.

\section{Conclusiones}

El pleito termina cinco años más tarde, con don Juan Rodríguez Pilco culpable de los cargos que se le imputan, condenado a seis años de destierro a veinte leguas del pueblo de Ambar, debiendo servir los tres primeros en el hospital de Santa Ana cuidando enfermos ${ }^{63}$, viudo y sumido en la pobreza luego de agotar su hacienda y la de sus hijos durante el tiempo que estuvo encarcelado ${ }^{64}$. Vemos aquí ilustrada la predicción del Virrey Toledo respecto del gasto que ocasiona en los indios esta cultura jurídica: «No se les ha quitado el mayor tributo y llaga que han tenido para el peligro de almas y cuerpos y empobrecellos que ha sido los pleitos» ${ }^{65}$. La última noticia que tenemos suya data del 26 de octubre de 1665, cuando el juez de apelaciones de Hua-

${ }^{63}$ Causa contra don Rodríguez Pilco, cacique y gobernador del pueblo de Ambar, por haber permitido a un yndio el hacer un simulacro de misa y de bautismo en la fiesta del Corpus, AAL, Hechicerías e Idolatrías, leg. IIA, exp. 12, Ambar 1661/1662, f. 368r.

${ }_{64}$ Rodríguez Pilco denuncia en varias oportunidades a través del procurador general de los naturales, Joseph Mexía, su condición de pobreza y enfermedad pidiendo «la ciudad por cárcel» - es decir, vivir fuera de la prisión pero sin abandonar del recinto urbano- para conseguir algún sustento, ya sea trabajando o pidiendo limosna, y sanar de sus males. Incluso llega a solicitar alimento a las recoletas de Nuestra Señora de la Guía para poder subsistir en prisión. Ibidem, f. $357 \mathrm{v}$.

${ }^{65}$ Levillier, 1921-26, vol. 3: 316. 
manga le otorga el permiso para la apelación junto con su calidad de pobre de solemnidad para evitar pagar las costas ${ }^{66}$. Aquí le perdemos el rastro, y no sabemos cuál fue la resolución de este tribunal.

Lo que podemos colegir es que luego de la fiesta del Corpus, a partir del escándalo público, se intentó volver a una normalidad «reforzada» a partir de estas prácticas jurídicas que prueban ser fallidas en este caso. La manipulación del sistema legal colonial en el caso de Ambar estuvo lejos de ser efectiva, puesto que si la intención fue no capitular al cura por lo costoso y extenso que podría haber sido el pleito, y creer que la Inquisición no intervendrá, es de notar que todo finaliza con los protagonistas arruinados económicamente por un proceso legal muy extenso, y el cura desterrado en otra doctrina (tenemos noticia de la presencia de Salazar Montesinos en el curato de San Pedro de Ticllos) y reemplazado por el bachiller Bernabé López de Burgos. Muchas veces los objetivos de los pleitos y capítulos no estaban encaminados a impugnar el sistema de dominación colonial como tal, sino a protestar contra funcionarios abusivos. Retar al sacerdote implicaba retar a toda la empresa colonial, pero sin llegar a deslegitimizarla.

La estrategia de los principales de Ambar parece haberse delineado a partir de una manera propia de concebir e interpretar el ejercicio de la autoridad: si los capítulos eran poco eficaces y los procedimientos judiciales, largos, costosos y engorrosos, entonces no quedaba más remedio que provocar un escándalo muy público, llevando a cabo una ceremonia que si bien podría ser considerada idolátrica, los dejaría, según el juicio de Rodríguez Pilco, fuera del alcance inquisitorial pero que, al tener un antecedente como el de la fiesta de la Candelaria, afectaría al cura, solucionando de alguna manera el problema. Esta concepción del ejercicio de la autoridad se pone de manifiesto en la lucha de poder dentro de la comunidad: por un lado, un cura desmedido, y por el otro, un curaca hábil en el manejo de las expectativas y normas para conseguir sus fines, y astuto en lo que respecta a cómo habrían de entenderse sus actos públicos, maniobrando de modo que sus acciones atraigan la atención y provoquen la actuación de las autoridades eclesiásticas. El escándalo provocado no es una falla o un malentendido en el aspecto cristiano de Rodríguez Pilco, sino que sería parte integral de la estrategia que despliega, una maniobra audaz y peligrosa que a su vez le da a Salazar Montesinos elementos para acusarlo de idolatría. Lo público del ritual es la provocación, porque a estas alturas, los naturales saben bien cómo practicar sus ritos disimulando,

${ }^{66}$ Causa contra don Rodríguez Pilco, cacique y gobernador del pueblo de Ambar, por haber permitido a un yndio el hacer un simulacro de misa y de bautismo en la fiesta del Corpus, AAL, Hechicerías e Idolatrías, leg. IIA, exp. 12, Ambar 1661/1662, ff.370 r-v. 
ocultando la idolatría o sin atraer la atención de la Iglesia. Quizás se trate de un desafío abierto al doctrinero que hace mal su trabajo y que termina acusado de abandono de feligresía y negligencia pastoral. Si bien otra interpretación del evento pudo haber sido la elaboración de estrategias de parte de los naturales para ocultar sus creencias verdaderas o adaptar el culto a una situación represiva ${ }^{67}$, creemos que, en el caso que nos ocupa, bien podría ser una exegesis un tanto simplista, puesto que a estas alturas, mediados del siglo XVII, como ya hemos señalado, hay cierta práctica y grados de efectividad a la hora de mantener el secreto, y por ende, la lectura política de los eventos nos parece la más adecuada.

La contraparte de esta estrategia política aquí esbozada es mostrarse buen indio y buen cristiano, presentarse como moralmente superior al clero español, verdadero modelo de virtud en relación con los abusos y maltratos propinados por los doctrineros y evitar así el alcance del castigo. En otras palabras, se trata de utilizar la celebración de la Candelaria y la supuesta actuación de Salazar Montesinos y presentarla como conducta recurrente, de la cual el cacique repudia y castiga con el mero hecho de no participar de tales comportamientos, a la vez que los denuncia. En suma, para Rodríguez Pilco no queda más que involucrarse en el asunto, accionar criticando las prácticas coloniales de una Iglesia desacreditada y de la propia justicia, y señalar así la falla de los religiosos en cumplir con las prescripciones de la iglesia posttridentina, que propone que sus doctrineros y sacerdotes enseñen con el ejemplo y sean espejo de virtudes para los indios ${ }^{68}$. Si el doctrinero no es ejemplo, no quedará más remedio que presentar uno propio, convertirse en el mejor cristiano y señalar las prácticas corruptas, llevando la política de la Iglesia a sus niveles más locales para accionar hacia arriba, apuntando a las jerarquías dentro de la comunidad. Y si el sistema falla, utilizar la falla para explotarlo desde dentro. El riesgo no medido por Rodríguez Pilco lo lleva a prisión, a un pleito muy largo e intrincado que lo arruina en hacienda y salud, y lo castiga con destierro.

Los curacas andinos, presos entre dos legitimidades, utilizaron estas estrategias legales y judiciales para insertarse en el mundo colonial, en un mundo que exigía de ellos una contrapartida que no necesariamente se ajustaba a sus atributos curacales anteriores a la conquista ${ }^{69}$. Las décadas de 1650 y 1660 , período de fuertes cambios, adaptaciones y transiciones en los Andes, fueron de muchos pleitos y quejas en el virreinato, la mayoría de ellas protagoniza-

\footnotetext{
${ }^{67}$ Gareis, 2004: 269-270.

68 Dueñas, 2015: 125.

${ }^{69}$ Puente Luna, 2007: 251.
} 
das por curacas y doctrineros, e incluso entre curacas, con el fin de deponer rivales, mejorar determinadas condiciones de vida dentro de las comunidades, o hacer tambalear momentáneamente el delicado equilibro del poder, aún en las doctrinas más pequeñas. La apropiación y manipulación del ámbito judicial por parte de los indios, como vemos en el caso de Ambar, sirvió como prácticas de negociación, de resistencia, $\mathrm{y}$, sobre todo, de alegato de una identidad problematizada.

\section{BiBLIOGRAFÍA}

Acosta Rodríguez, Antonio, "El pleito de los indios de San Damián (Huarochirí) contra Francisco de Ávila, 1607”, Historiografía y bibliografia americanista, 23 (Sevilla, 1979): 3-33.

Acosta Rodríguez, Antonio, "Los doctrineros y la extirpación de la religión indígena en el Arzobispado de Lima, 1600-1602", Jahrbuch für Geschichte von Staat, Wirtschaft und Gesellschaft Lateinamerikas, 19 (Köln Graz, 1982a): 69-109.

Acosta Rodríguez, Antonio, "Los clérigos doctrineros y la economía colonial (Lima, 1600-1630)", Allpanchis. Revista del Instituto de Pastoral Andina, 16/19 (Arequipa, 1982b): 117-150.

Acosta Rodríguez, Antonio, "Religiosos, doctrinas y excedente económico indígena en el Perú a comienzos del siglo XVII", Histórica, VI/1 (Lima, 1982c): 1-34.

Acosta Rodríguez, Antonio, "La extirpación de las idolatrías en el Perú. Origen y desarrollo de las campañas. A propósito de Cultura andina y represión, de Pierre Duviols", Revista Andina, 1 (Cuzco, 1987): 171-195.

Aguirre, Carlos, "Tinterillos, Indians, and the State. Towards a History of Legal Intermediaries in Post-Independence Peru", Stefan B. Kirmse (ed.), One Law for All? Western Models and Local Practices in (Post-) Imperial Contexts, Frankfurt, Campus Verlag, 2012: 119-151.

Alaperrine-Bouyer, Monique, "Recurrencias y variaciones de la imagen del cacique", Bernard Lavalle (ed.), Máscaras, tretas y rodeos del discurso colonial en los Andes, Lima, Pontificia Universidad Católica del Perú, 2005: 189-210.

Assadourian, Carlos Sempat, "Dominio colonial y señores étnicos en el espacio andino", Transiciones hacia el sistema colonial andino, Lima, El Colegio de México / Fideicomiso Historia de las Américas, 1994: 7-20.

Cahill, David, "Curas and Social conflict in the Doctrinas of Cuzco, 1780-1814", Journal of Latin American Studies, 16 (Cambridge, 1984): 241-276.

Castañeda Delgado, Paulino y Hernández Aparicio, Pilar, La Inquisición de Lima: 1570-1635, Madrid, Deimos, 1989. 
Charles, John, "Testimonio de coerción en las parroquias de indios: Perú, siglo XVII", Ana Zavalla Beaescoechea (ed.), Los indios ante los foros de justicia religiosa en la Hispanoamérica virreinal, México, Universidad Nacional Autónoma de México, 2010: 111-126.

Charles, John, "Guamán Poma en los foros de justicia eclesiástica", Ana Zaballa Beascoechea (ed.), Los indios, el Derecho Canónico y la justicia eclesiástica en la América virreinal, Madrid, Iberoamericana / Vervuert, 2011: 203-222.

Constituciones Sinodales del Arçobispado de los Reyes en el Peru, 1636. Sínodos de Lima de 1613 y 1636, Madrid, Centro de Estudios Históricos del Consejo Superior de Investigaciones Científicas / Instituto de Historia de la Teología Española de la Universidad Pontificia de Salamanca, 1987.

Domínguez Reboiras, Fernando, "La Inquisición española y los indios", Wulf Oesterreicher y Roland Schmidt-Riese (eds.), Esplendores y miserias de la evangelización en América. Antecedentes europeos y alteridad indígena, Berlín, De Gruyter, 2010: 45-71.

Dueñas, Alcira, "The Lima Indian Letrados: Remaking the República de Indios in the Bourbon Andes", The Americas: A Quarterly Review of Latin America, 72/01 (Cambridge, 2015): 55-75.

Duviols, Pierre, La destrucción de las religiones andinas (conquista y colonia), México, Universidad Nacional Autónoma de México, 1977.

Espinosa Soriano, Waldemar, "El alcalde mayor indígena en el virreinato del Perú", Anuario de Estudios Americanos, 17 (Sevilla, 1960): 183-300.

Estenssoro Fuchs, Juan Carlos, Del paganismo a la santidad: la incorporación de los indios del Perú al catolicismo, 1532-175, Lima, Institut Francais d'Etudes Andines, Pontificia Universidad Católica del Perú, 2003.

Flores Galindo, Alberto, "Comunidades y doctrinas: la disputa por las almas (Sierra Central, 1608-1666)", Buscando un inca: identidad y utopía, Lima, Instituto de Apoyo Agrario, 1987: 85-106.

Flores Ochoa, Jorge A., "Historia, fiesta y encuentro en el Corpus Christi cuzqueño", La fiesta en el arte, Lima, Banco de Crédito del Perú, 1994: 39-59.

García Cabrera, Juan Carlos, Ofensas a Dios. Pleitos e injurias. Causas de idolatrías y hechicerías, Cajatambo, siglos XVII-XIX, Cusco, Centro de Estudios Regionales Andinos Bartolomé de Las Casas, 1994.

Gareis, Iris, "Extirpación de idolatrías e Inquisición en el virreinato del Perú", Boletín del Instituto Riva Agüero, 16 (Lima, 1989): 55-74.

Gareis, Iris, "Repression and cultural change: The 'Extirpation of Idolatry' in Colonial Peru", Nicolas Griffiths y Fernando Cervantes (eds.), Spiritual Encounters. Interactions between Christianity and Native Religions in Colonial America, Birmingham, The University of Birmingham Press, 1999: 230-254. 
Gareis, Iris, "Extirpación de idolatrías e identidad cultural en las sociedades andinas del Perú virreinal (siglo XVII)", Boletín de Antropología de la Universidad de Antioquia, 18/35 (Medellín, 2004): 262-282.

Greenleaf, Richard E., "The inquisition and the Indians of New Spain: A Study in Jurisdictional Confusion", The Americas, 22/2 (Cambridge, 1965): 138-166.

Gutiérrez Arbulú, Laura, "Índice de la sección hechicerías e idolatrías del Archivo Arzobispal de Lima", Gabriela Ramos y Henrique Urbano (comps.), Catolicismo y extirpación de idolatrías. Siglos XVI-XVIII, Cusco, Centro de Estudios Regionales Andinos Bartolomé de Las Casas, 1993: 105-136.

Hampe Martínez, Teodoro, "Control moral y represión ideológica: al Inquisición en Perú (1570-1820)", Culture et Societé. Andes et Mesoamerique: Melanges en hommage a Pierre Duviols, Aix-en-Provence, Université de Provence, 1991: 441453.

Hampe Martínez, Teodoro, "Recent Works on the Inquisition and Peruvian Colonial Society, 1570-1820", Latin American Colonial Review, 31/2 (Philadelphia, 1996): 43-65.

Honores, Renzo, "Litigando en la Audiencia: El devenir de un «Pleyto»", Historia y Cultura, 22 (Lima, 1993): 27-45.

Honores, Renzo, "Estudios sobre la litigación y la litigiosidad colonial", Revista de Historia del Derecho Privado, 2 (Valparaíso, 1999): 121-35.

Honores, Renzo, "Pleytos, letrados y cultura legal en Lima y en Potosí, 1540-1640", Latin American Studies Asociation XXVI International Congress, 2006.

Huertas Vallejos, Lorenzo, La religión en una sociedad rural andina, siglo XVII, Lima, Universidad San Cristóbal de Huamanga, 1981.

Hunefeldt, Christine, "Comunidad, curas y comuneros hacia fines del período colonial: Ovejas y pastores indomados en el Perú", HISLA: Revista Latinoamericana de Historia Económica y Social, 2 (Lima, 1983): 3-31

Lavallé, Bernard, "Las doctrinas indígenas como núcleos de explotación colonial", Allpanchis, Revista del Instituto de Pastoral Andina, 16/19 (Arequipa, 1982): 151-172.

Levillier, Roberto, Gobernantes del Perú. Cartas y papeles del s. XVI. Documentos del Archivo de Indias, Madrid, Sucesores de Rivadeneira, 1921-1926, 14 vols.

Lobo Guerrero, Bartolomé y Arias de Ugarte, Fernando, Sínodos de Lima de 1613 a 1636, Madrid, Centro de Estudios Históricos del Consejo Superior de Investigaciones Científicas, 1987.

Medina, José Toribio, Historia del Tribunal del Santo Oficio de la Inquisición de Lima (1569-1820), Santiago, Imprenta Gutenberg, 1887, 2 vols. 
Millar Carvacho, René, La Inquisición de Lima (1697-1820), Madrid, Deimos, 2005.

Millones, Luis, "Los ganados del señor: mecanismos de poder en las comunidades andinas, siglos XVII y XVIII", América Indígena, 39/2 (Ciudad de México, 1978): 107-145.

Millones, Luis, "Shamanismo y política en el Perú colonial: los curacas de Ayacucho", Histórica, 8/2 (Lima, 1984): 131-149.

Mills, Kenneth, Idolatry and Its Enemies. Colonial Andean Religion and Extirpation, 1640-1750, Princeton, Princeton University Press, 1997.

Monsalve Zanetti, Martín, "Miserables e idólatras: los curacas frente a la administración eclesiástica", Actas del IV Congreso Internacional de Etnohistoria, Lima, PUCP, 1998: 376-398.

Pease, Franklin, Curacas, reciprocidad y riqueza, Lima, Pontificia Universidad Católica del Perú, 1992.

Pease, Franklin, “¿Por qué los andinos son acusados de litigiosos?”, Marco Borghi (ed.), Derechos culturales, Lima / Friburgo, Pontificia Universidad Católica del Perú / Universidad de Friburgo, 1996: 27-37.

Poloni-Simard, Jacques, "Los indios ante la justicia: el pleito como parte de la consolidación de la sociedad colonial", Bernard Lavallé (ed.), Máscaras, tretas y rodeos del discurso colonial en los Andes, Lima, Instituto Francés de Estudios Andinos / Pontificia Universidad Católica del Perú, 2005: 177-188.

Puente Luna, José Carlos de la, Los curacas hechiceros de Jauja. Batallas mágicas y legales en el Perú colonial, Lima, Pontificia Universidad Católica del Perú, 2007.

Puente Luna, José Carlos de la, "That Which Belongs to All: Khipus, Community, and Indigenous Legal Activism in the Early Colonial Andes", The Americas: A Quarterly Review of Latin American History, 72/01 (Cambridge, 2015): 19-54.

Ramírez, Susan Elizabeth, “The 'Dueno [sic] de Indios': Thoughts on the Consequences of the Shifting Bases of Power of the 'Curacas de los Viejos Antiguos' under the Spanish in Sixteenth-Century Peru", Hispanic American Historical Review, 67/4 (Durham, 1987): 575-610.

Ramírez, Susan Elizabeth, The World Upside Down. Cross-Cultural Contact and Conflict in Sixteenth-Century Peru, California, Stanford University Pres, 1996.

Ramos, Gabriela, "La privatización del poder: Inquisición y sociedad colonial en el Perú", Henrique Urbano (ed.), Poder y violencia en los Andes, Cusco, Centro de Estudios Regionales Andinos Bartolomé de Las Casas, 1991: 75-92.

Rivarola, José Luis, Español andino. Textos de bilingües de los siglos XVI y XVII, Madrid, Vervuert Iberoamericana, 2000. 
Rivarola, José Luis, "Los indios capitulan a su cura. Sobre lengua y sociedad en el Perú andino del s. XVII", Wulf Oesterreich (ed.), Esplendores y miserias de la evangelización en América: europeos y alteridad indígena, Berlin, De Gruyter, 2010: 213-245.

Robins, Nicholas A., Comunidad, clero y conflicto. Las relaciones entre la curia y los indios en el Alto Perú, 1750-1780, La Paz, Plural, 2009.

Rowe, John H., "The Incas under Spanish Colonial Institutions", Hispanic American Historical Review, 37/2 (Durham, 1957): 155-99.

Solórzano Pereira, Juan de, Política Indiana, Madrid, Biblioteca de Autores Españoles, 1972, vol. V: 252-256.

Spalding, Karen, "Kurakas and Commerce: A Chapter in the Evolution of Andean Society", Hispanic American Historical Review, 53/4 (Durham, 1973): 581-599.

Spalding, Karen, "Resistencia y adaptación: el gobierno colonial y las elites nativas"; Allpanchis. Revista del Instituto Pastoral Andina, 1/17 (Arequipa, 1974): 31-60.

Spalding, Karen, Huarochiri: An Andean Society Under Spanish Rule, Sanford, University Press, 1984.

Spalding, Karen, "Defendiendo el suyo. El kuraka en el sistema de producción andina", Reproducción y transformación de las sociedades andinas, siglos XVI-XX, Quito, Abya-Yala, 1991: 401-414.

Spalding, Karen, "La otra cara de la reciprocidad", Jean-Jacques Decoster (ed.), Incas e Indios cristianos. Elites indígenas e identidades cristianas en los Andes coloniales, Cuzco, Centro Bartolomé de Las Casas, 2002: 61-78.

Stanic, Ana, "Los elementos subversivos de la fiesta colonial unificadora: el caso de la fiesta del Corpus Christi dentro del diseño estratégico de la escritura del inca Garcilaso de la Vega", Mariela Insúa y Martína Vinatea Recoba (eds.), Teatro y fiesta popular y religiosa, Pamplona, Universidad de Navarra, 2013: 365-377.

Tineo Morón, Melecio (ed.), La fe y las costumbres: Catálogo de la sección documental de Capitulos (1600-1898), Archivo Arzobispal de Lima, Cuzco, Centro Bartolomé de Las Casas, 1992.

Tineo Morón, Melecio, Catálogo de la Serie Documental de Curatos del Archivo del Obispado de Huacho (1600-1979), Lima, Quellca, 2016.

Villagómez, Pedro de, Carta pastoral de exhortación e instrucción acerca de las idolatrías de los indios del arzobispado de Lima, Lima, Jorge López de Herrera impresor de libros, 1649.

Zaballa Beascoechea, Ana (ed.), Los indios, el Derecho Canónico y la justicia eclesiástica en la América virreinal, Madrid, Iberoamericana / Vervuert, 2001. 
Zevallos Quiñones, Jorge, "Consideraciones sobre la fiesta del Corpus en Cajamarca en el año 1684", Francisco Miró Quesada y Franklin Pease (eds.), Historia, Problema, Promesa, Lima, Pontificia Universidad Católica del Perú, 1978: 621-635.

Zinni, Mariana C., "«Irrisión del sancto sacrificio de la misa»: simulacro y mimesis en una doctrina de indios en los Andes, siglo XVII", Revista Andina, 55 (Cuzco, 2017): $187-214$.

Fecha de recepción: 15 de febrero de 2019.

Fecha de aceptación: 5 de noviembre de 2019.

\section{"The Inquisition does not know us, the Indians": festival and scandal at Corpus Christi}

In 1661, during the Corpus Christi festival in the ecclesiastical district of Ambar, a series of episodes classified as idolatrous were carried out by the village's native inhabitants in the absence of the Catholic priest. These included the celebration of a false mass, a marriage union between two men in costume, and the baptism of the fruit of that union. This paper interprets these incidents with a view to exploring what drove a group of individuals with varying degrees of social status and access to power - the Indian sacristan, the curaca, the falso celebrant - who took advantage of the occasion to undermine the authority of the Catholic priest before the ecclesiastical tribunal, believing they were beyond its reach because of their indigenous condition. However, nothing turned out as they had planned and the events ended very differently.

KeY words: Indian Doctrine; Inquisition; Corpus Christi; Chapters; Colonial Andes. 
